\title{
ナイロンを幹とするグラフト重合体繊維の性質
}

\author{
東洋レーヨン株式会晳 篠 原 康夫・向山鋭次
}

\section{PROPERTIES OF NYLON GRAFT FILAMENTS}

\section{By Yasuo Shinohara and Eiji Mukoyama}

(Central Research Laboratry, Toyo Rayon Co. Ltd., Otsu City, Shiga Prefecture, Japan)

Styrene, methyl methacrylate, acrylonitrile, vinyle acetate, methyl acrylate and ethyl acrylate were grafted to nylon fiaments by pre-irradiation method and various properties of these graft copolymer filaments were measured.

For nylon-styrene graft, Young's modulus and torsional rigidity increased and tensile strength and elastic recovery decreased. Various vinyl monomers which were grafted onto nylon are divided into two groups. The first group which includes styrene, MMA and acrylonitrile has the same properties of the nylon-styrene graft. Young's modulus and torsional rigidity of the second group which includes MA and EA decreased, VAC is an intermediate between these two groups.

This classification clearly relates to the second order transition temperatures of the vinyl homopolymers. The second order transition temperature of the first group is higher than that of the Nylon and the second group has the lower second order transition temperature.

(Received July 10, 1961)

\section{I. 舶言および重合方法}

最近放射線を利用する，または化学的方法によるグラ フト重合以関する研究は極好多くなつてきた。いかし ながらこのよらな研究もグラフト重合方法化関する研究 が大多数であり，グラフト重合体の性質はどらであるか といらことに関する研究はあまり多くない。今後グラフ 卜重合体を実際的に利用し得るためには，グラフト重合 体の構造执よび性質に関する研究を押し進めてゆくびき であると考觉る。この報告はナイロン翰とするグラフ 卜重合体の㵶維の絨維としての性質について二, 三調べ た結果老述べる。

グラフト重合の方法は，陚料学 Van de Graaff 型加 速器により空気中で 1 3 M rad照射しこれを空気老 䟻いた状態に扩いてビニルモノマーィタノール水混合系 之接触させ $60^{\circ} \mathrm{C} て ゙ 1 〜 5$ 時間加熱する。グラフト憅合 反応を終了してから，枝ビニールポリマーの溶剂でよく

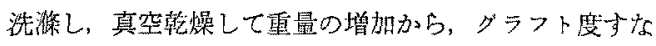
わち校ビニルポリマー重量の元ナイロロン重量比対する 比を求就た。

\section{II. グラフト重合による形態の変化}

$$
\text { ナイロンにスチレンをグラフト重合させた陚料につい }
$$

て形態の変化は, 次のようである。 延伸系汇执いては，グラフト重合は横方向のみ燋行 する。すなわち，横方向試料は膨脤し綖方向には伸び ない。このことは第工表からわかるとおりである。

第 1 表 グラフト重合による太さの変化

\begin{tabular}{|c|c|c|c|c|c|c|}
\hline 試 & 料 & $\begin{array}{l}\text { プ } \\
2 \%\end{array}$ & $31 \%$ & $45 \%$ & $67 \%$ & $80 \% 105 \%$ \\
\hline \multicolumn{2}{|c|}{ 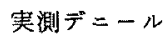 } & 3.10 & 4. 30 & 5.05 & 5.74 & \begin{tabular}{l|l}
5.94 & 6.59
\end{tabular} \\
\hline \multicolumn{2}{|c|}{ 計算デ $=-ル$} & - & 4.06 & 4.50 & 5.18 & \begin{tabular}{|l|l|}
5.58 & 6.36
\end{tabular} \\
\hline \multicolumn{2}{|c|}{ 比 } & - & 1.06 & 1.12 & 1.11 & \begin{tabular}{l|l}
1.06 & 1.04
\end{tabular} \\
\hline
\end{tabular}

ここで計算デニールといらのは横方向のみにグラフト 重合したと考光てグラフト度から計算したものである。 多少実測值が計算值より大きいのは, ダラフト重合を行

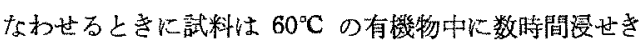
されているのでこの間にいくらかの収縮を生したためと 考えられる。

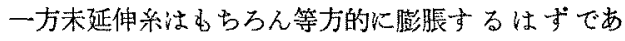
る。実際未延伸系について，(1十グラフト度）の立方根 とデニール比の平方根とは大体一致した。

$$
\text { III. ナイロンースチレン系クラフト }
$$

$$
\text { 重合体の力学的性質について }
$$

第2 表に $3 \mathrm{~d}$ のステープルを元原料としてこれにスチ 
第 2 表 グラフト重合したナイロンステーブルの性留

\begin{tabular}{|c|c|c|c|c|c|c|c|c|c|c|}
\hline \multicolumn{5}{|c|}{ 項 目 試 料 } & $\begin{array}{l}\text { ブラ } \\
\text { ンク }\end{array}$ & $31 \%$ & $45 \%$ & $67 \%$ & $80 \%$ & $105 \%$ \\
\hline \multicolumn{4}{|c|}{ 平衡水分率 } & $\%$ & 4.8 & 2.8 & 2.6 & 2.5 & 2.1 & 2.0 \\
\hline \multicolumn{4}{|c|}{ 見 满 度 } & d & 3. 10 & 4. 30 & 5.05 & 5.74 & 5.94 & 6.59 \\
\hline \multirow{2}{*}{ 強 } & & & & $\mathrm{g} / \mathrm{d}$ & 5.00 & 3.63 & 3.08 & 2.91 & 2.77 & 2.46 \\
\hline & & 湿 & & $" \prime$ & 4.22 & 2.94 & 2.56 & 2.38 & 2.11 & 1.85 \\
\hline \multirow{2}{*}{ 度 } & 結 & & 節 & " & 4.58 & $3 \cdot 41$ & 3.06 & 2.97 & 2.62 & 2. 22 \\
\hline & 引 & & 掛 & $"$ & 8.24 & $5.10^{\prime}$ & 4.64 & 4. 16 & 4.37 & 4.03 \\
\hline \multicolumn{4}{|c|}{ 乾強力変動率 } & $"$ & 13.5 & 13. 2 ! & 14.3 & 12.8 & 14.9 & 11.7 \\
\hline 強 & 乾 & & 湿 & " & 84 & $81^{\prime}$ & 83 & 82 & 76 & 75 \\
\hline 力 & 結 & & 節 & $"$ & 92 & 94 & 100 & 102 & 95 & 90 \\
\hline 比 & 引 & & 趣 & $"$ & 165 & 141 & 151 & 142 & 158 & 164 \\
\hline 伸 & & 乾 & & $"$ & 45.4 & 55.7 & 61.1 & 62.5 & 67.4 & 77.5 \\
\hline 度 & & 湿 & & $" \prime$ & 48.0 & 57.7 & 61.3 & 62.5 & 74.2 & 66.7 \\
\hline$\approx 1$ & & サ茼 & 性 & $\mathrm{cm}$ & 3.10 & 4.03 & 4.08 & 3.95 & 4.65 & 4.60 \\
\hline & & 樎 & & $\%$ & 83.5 & 78.1 & 79.5 & 77.6 & 76.3 & 78.1 \\
\hline 法 & & 回 & & $"$ & 9.0 & 11.9 & 14.0 & 10.4 & 15.8 & 17.5 \\
\hline+ & 2 & $\not r$ & 率 & $\mathrm{g} / \mathrm{d}$ & 10.4 & $14.4_{\text {I }}$ & 13.1 & 14.4 & 18.7 & 19.4 \\
\hline
\end{tabular}

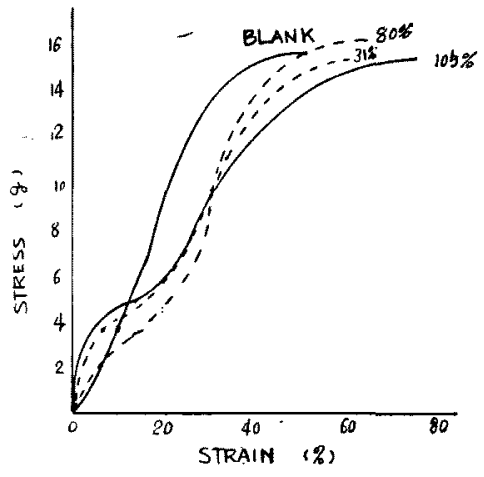

Fig.1. Stress-strain curves of nylonstyrene graft copofymers.

はずであるが，第1図に示すよ5に実際はそ うでない。ここで添字はグラト度を表示し てある。

大きい2つの差が見られる。それはグラフ ト度の增加とともに初期の立上り，すな⿰七 ヤング率が大きくなることがその一つであ

レンをグラフト重合させた試料の繊維としての性質のデ 一タをまとめて示しておく。

\section{1. 強力について}

第1表からわかるよらに強度 $(\mathrm{g} / \mathrm{d})$ はダラフト度が大 きくなるにつれて低下してゆく。しかしながら第了表か らわかるよらに强力 $(\mathrm{g})$ そ机自身はダラフト重合によつ て変化しない。

第 3 表 グラフト試料の強力

\begin{tabular}{|c|c|c|c|c|c|c|c|}
\hline 試 & 料 & $\begin{array}{l}759 \\
29\end{array}$ & $31 \%$ & $45 \%$ & $67 \%$ & $80 \%$ & $105 \%$ \\
\hline 乾 & 強力 & 15.5 & 15.6 & 15.6 & 16.7 & 16.5 & 16.2 \\
\hline 湿 & "I & 13. 1 & 12.6 & 12.9 & 13.7 & 12.5 & 12.2 \\
\hline 結節 & " & 14.2 & 14.7 & 15.3 & 17.0 & 15.6 & 14.6 \\
\hline 引清 & $"$ & 25.6 & 21.9 & 23.4 & 23.9 & 26.0 & 26.6 \\
\hline
\end{tabular}

乾強力变動率，强力比がグラフト度の变化によつて市 まり変わらないのは，これから当然のことである。

以上のことから強力はナイロン部の不によつて和り， スチレン部の笴与は注とんどないことを意味している。 また一方グラフト重合といら作用によつても、ナイロン 自体の強力はそこなわれていないことになる。

\section{2. 强伸度曲線およびヤング率について}

以上の强力た゚けからの考察からでは、スチレンは単に 試料を太くしているたけであって，他に何らの等与もし ない上らに思われる。もしそらであるなら，強伸度曲線 をg対\%のスケールで畫けばグラフトしてむ梦化しない
ク，むら一つは伸度が增加することである。この相違と 既述した強力があまり変わらないといら二つの点につい て考えてみる。

この問題について非常にあらい近促としてグラフト試 料はナイロンとポリエチレンの性質の和として表わされ るむのと考えて及上よう。この場合もちろんポリスチレ ンは延伸されていない。末延伸ポリスチレンの强度は大 体 $0.3 \mathrm{~g} / \mathrm{d}$ ，ヤング率は $30 \mathrm{~g} / \mathrm{d}$ 位である。伸度はもらろ ん大きく $100 \%$ 以上である。袹度が小さいとからグ フト陚料の㧧力に片スチレンの分が，寄与しないこと はこれで理解できる。次にポリスチレンのヤング率を27 g/d としてスチレンによるナンダ㸉の寄与とナイロンK よるそれとの和上してグラフト陚料のヤング率計算しれ ものと，㬰測値との比較を第 4 表に示声。大きい近似と しては大体一致している。

第 4 表 グラフト試料のヤング率

\begin{tabular}{|c|c|c|c|c|c|c|}
\hline 試 & $\begin{array}{l}\text { ブラ } \\
ン タ\end{array}$ & $31 \%$ & $45 \%$ & $67 \%$ & $80 \%$ & $105 \%$ \\
\hline 計算ヤ゙ング菜 $(\mathrm{g} / \mathrm{d})$ & 10.4 & 14.4 & 15.6 & 17.1 & 17.8 & 18.9 \\
\hline 実测ヤング率 $(\mathrm{g} / \mathrm{d})$ & 10.4 & 14.4 & 13.1 & 14.4 & 18.7 & 19.4 \\
\hline
\end{tabular}

次に伸度については，グラフト度の增加とともに增加 してゅく。このことはポリスチレンの伸度が大きいため と一応は解釈できる。

以上を総合して，少なくとも縦方向の変形に対する力 学的性筫は，延伸ナイロンと末延伸ポリスチレンの性質 


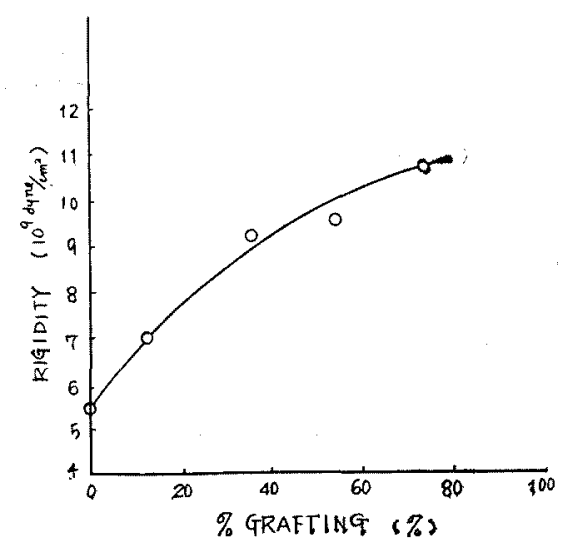

Fig.2. Torsional rigidities of nylon-styrene grat copolymers.

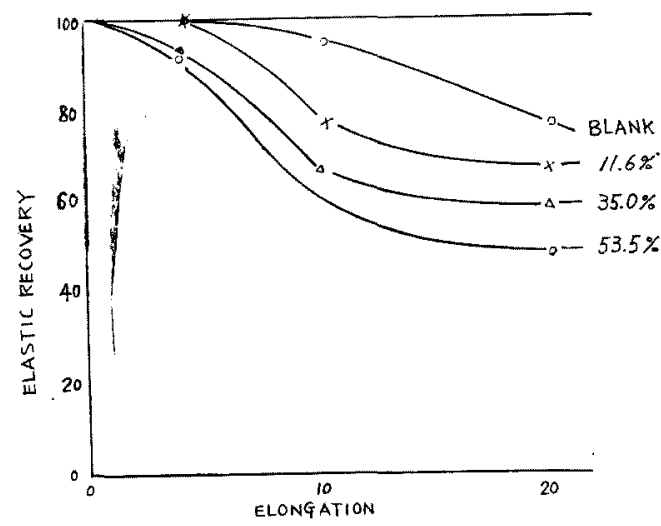

Fig.3. Elastic recovery of nylon-styrene graft copolymers.

の和として考えるともつとる考光やすいことになる。

\section{3. 別性率について}

$15 \mathrm{~d}$ 延伸系について調べてみた。グラフト試料の剛性 草は第 2 図に示すよらにダラフト度とともに增加する。 唰性萃の測定は自由振動法による。

\section{4. 回復性について}

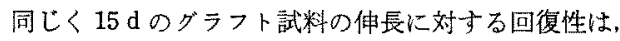
第 3 图のよらであつて，グラフト度の增加とともに悪く なる。高伸長の場合は低伸長の場合よりその程度が著し い。第 4 図は 4，10，20\% 伸長し， 1 分間固定し，元に もどして 1 分間放置したときの回復率を示す。

\section{5. 未延伸状でグラフト重合した場合}

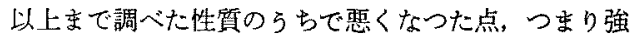
度が下がること怙よび回復性が悪くなることは，いずれ も未姃伸のポリスチレンを含んでいるためと考えられ

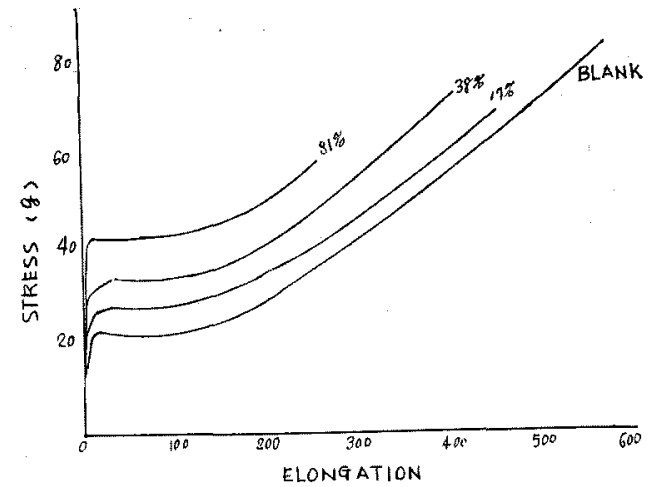

Fig. 4. Stress-strain curves of undrown nylon-styrene groft copolymers.

る。したがつて未延伸ナイロンにスチレンをグラフト重 合し，それからこれを延伸すれば上記の欠点を相当力バ 一できるらに思われる。しかしながら残念なことに第 4 図に示すよらな未延伸グラフト試料の強伸度曲線から 考えてみると，グラフト陚料は伸度が小さく，したが て冷延伸が困蜼である5と推定される。もつともこの点 にはまだ考虑の余地は分あると考えられる。

\section{IV，吸水性と染色性について}

第 2 丧に示すよらに平衝水分率はグラフト度の增加と ともに低下してゆく。ボリスチレンは侸とえど吸水性を 有しないことから考壳てナイロン部のみが吸水にあずか ると考充てよさそうである。実際ナイロン部のみが吸水 するとして計算した結果は第 5 表にに示すように上記の 考方方を大体支持している。

第 5 表 グラフト試料の水分率

\begin{tabular}{|c|c|c|c|c|c|c|}
\hline 試 & {$\left[\begin{array}{l}\text { ブラ } \\
\text { ンタ }\end{array} \mid\right.$} & $31 \%$ & $45 \% 6$ & $67 \%$ & $80 \%$ & $105 \%$ \\
\hline 水 分率 (実 測) & 4.8 & 2.8 & 2.6 & 2.5 & 2.1 & 2.0 \\
\hline $\begin{array}{l}\text { ナイロンの多が昨水す } \\
\text { るとしてナイロン部分 } \\
\text { だけの水分率 }\end{array}$ & 4.8 & 3.7 & 3.8 & 4.2 & 3.8 & 4.1 \\
\hline
\end{tabular}

染色性は吸水性と平行関係があり，グラフト度の堌加 とともに染色性は悪くなるものと考光られる。史際染色 してみた結果はやはりその通りであつた。

\section{V. 耐熱性と熱固定性について}

普通のポりスチレンは非晶性であり融点持たない が，それの流動し始める軟化点はだいたい 80 90 ある。したがつてグラフト試料もこの温度で流動はせず とも互に単織維同志がくつつく心配が考えられたが，調 ベてみた結果は $210^{\circ} \mathrm{C}$ 位までは大丈夫であることがかか つた。 


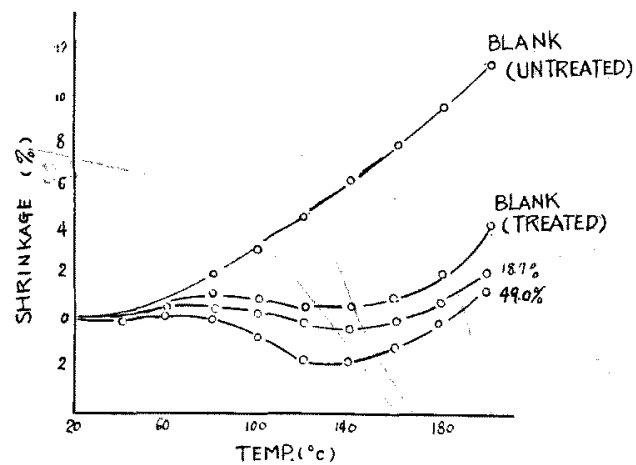

Fig.5. Shrinkage af nylon-styrene graft copolymers.

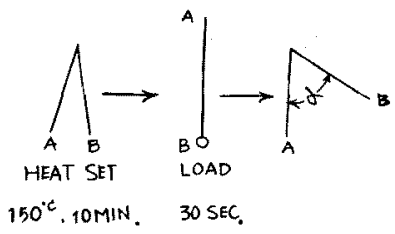

F!g. 6. Method for measuring the heat set property.

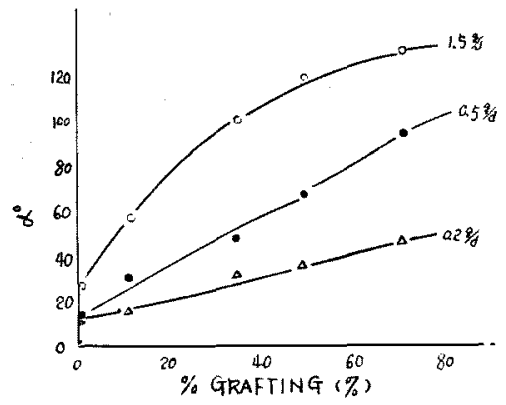

Fig.7. Heat set properties of nylon-styrene graft copolymers.

熱收縮は第6 図に示すようであり収縮率は少なくな る。これは $15 \mathrm{~d}$ の延伸系に $400 \mathrm{mg}$ の荷重をかけて温度 を上げながら収縮を測定した。この現象はグラフト重合 したためでもあるが，一部はスチレン，タタールなど の有機液体中で加熱したためである。ブランク（未処理） は文字ど和りのもの。ブランク（処理）は禁止凧を入れ ておいてグラフト重合は生起させずに，スチレン，メタ ノール水溶液中で $60^{\circ} \mathrm{C} 1.5 \mathrm{hr}$ 加熱したものである。 次熱固定性については次のような方法で調べてみ た。これは第 6 図のよ5に系を $180^{\circ} \mathrm{C}$ 折りまげ， $150^{\circ} \mathrm{C}$ で 10 分間熱固定した後 $0.2,0.5$ および $1.5 \mathrm{~g} / \mathrm{d}$ の荷 重をかけ，30 悡してから荷重を除き残留せる角度 $\alpha$ を
はからたものである。

このようにして測定した結果は，第 7 図に示すごとく グラフト度の增加ととすに熱固定性は悪くなる。グラフ ト試料のトウをクリンパーにかけてみるとブランクナイ ロンと大体同じよらにクリブがかかるが，その保持性は 多少悪くなるよらである。

\section{VI. いろいろなグラフト重合体のカ学的性質}

次にスチレン以外のビニルモノマーをグラフト重合さ せると、どうなるかという点について調へててみた。用い たビニルモノマーは，メタクリル酸メチル，アクリロ二 トリル，酢酸ビニル、フクリル酸メチル、フクリル酸工 テルである。

\section{1. 強伸度曲䌨}

$15 \mathrm{~d}$ の延伸ナイロン系を幹とするグラフト重合体の強

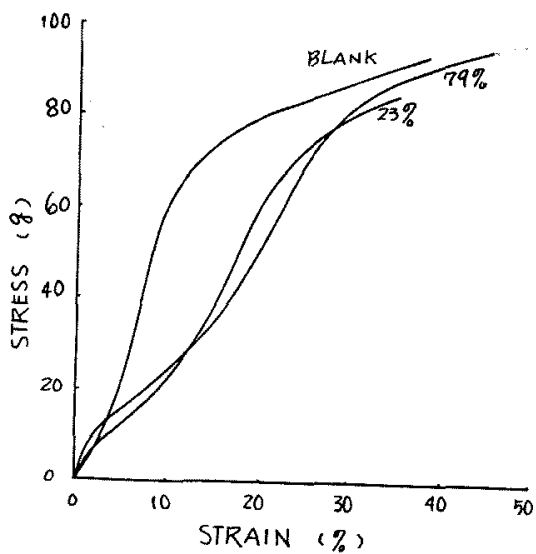

Fig. 8(1). Stress-strain curves of nylon-MMA graft copolymers.

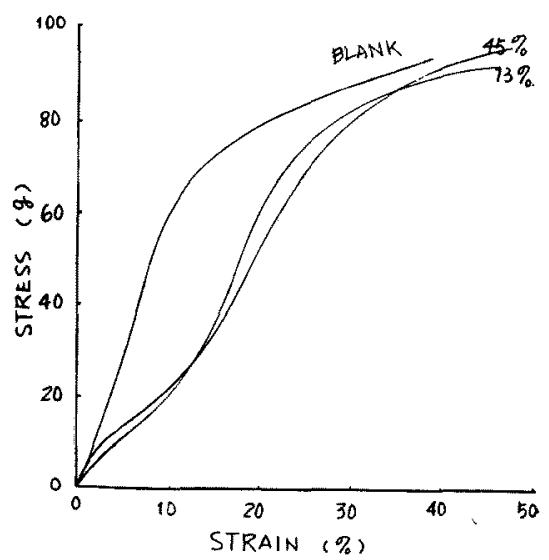

Fig. 8(2): Stress-strain curves of nylonAN graft copolymers. 


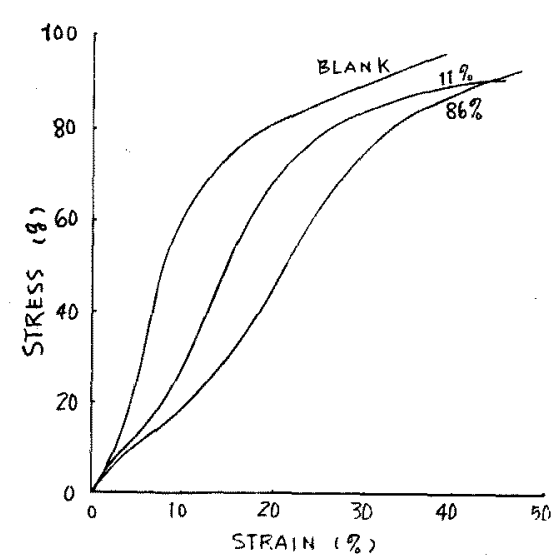

Fig. 8(3). Stress-strain curves of nylonVAc graft copolymers.

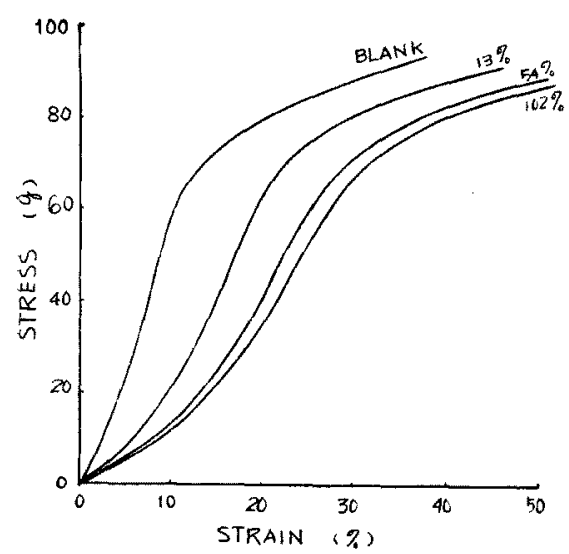

Fig.8(4). Stress-strain curves of nylonNA graft copolymers.

伸度曲線は第 8 図(1)〜(5)のようになつた。これから 得られることは，

(a) 強力にはあまり変化のないこと。ただしグラフ ト重合により采は太くなつているので, 強力を( $\mathrm{g} / \mathrm{d})$ で 表示すれば，それだけ低下する。このことは強力はナイ ロンでむつて就り，付加されたビニルポリマーの寄与は ほとんどなく，また逆にこれがナイロンを弱めるわけで 尼ないことを示している。

(b) 伸度は多少增大の傾向がある。

(c) 強力 $30 \mathrm{~kg}$ 程度以下に颃いて伸長が大きくなる こと。これはビニルボリマーが可塑剂のよらな役割安果 しているのであらら。

（d） MMA，AN の埸合初期の立上り（ヤング率） が大きくなり，VAc はほとんど変わらず，MA，EAで

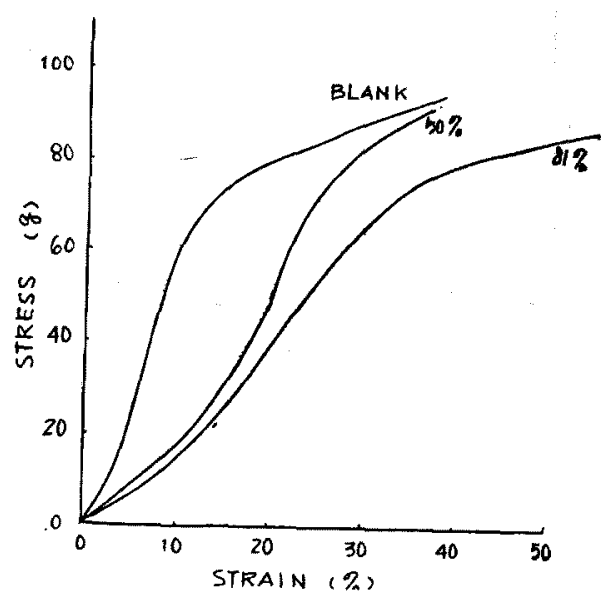

Fig. 8( 5 ). Stress-strain curves of nylon-EA graft copolymers.

は小さくなること。

奏際上糸の硬さを規定するのは初期の立上りである。 これをるつとはつきりさせるために動力学的な測定によ り剛性率を求めた。

\section{2. 剛性率}

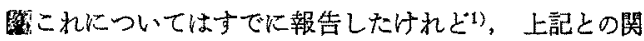
係をはつきりさせるために再録して必く。

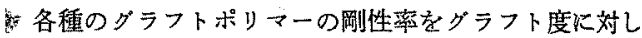
てプロットすると第 9 图のようになる。この㓮性率の変 化は Iで述へたたらに強伸度曲線の初期の立上りと完全

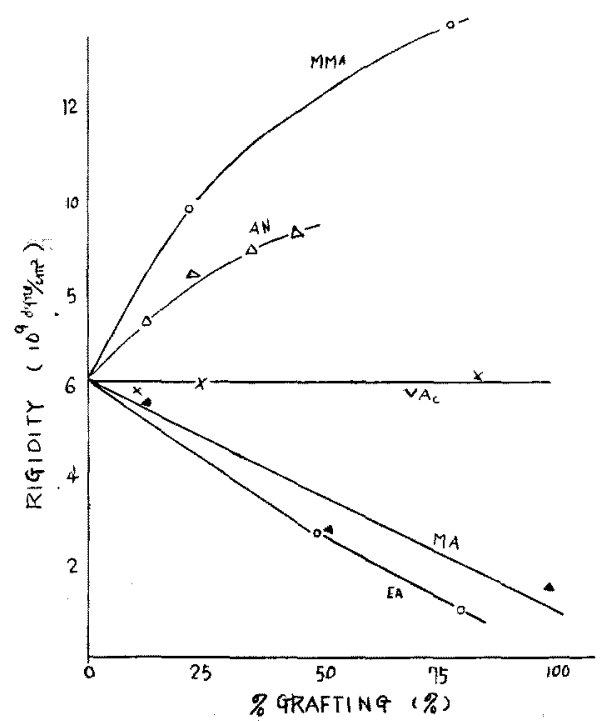

Fig.9. Torsional rigidities of various graft copolymers. 
飞対応している。すなわち MMA, AN は強伸度曲線の 初期の立上りおよび用性率は大きくなる。VAcはある 変化がなく，MA，EA は逆に両者とも小さくなる。平た くいえば，MMA，AN はナイロンを硬くし，VAcはあ まり変わらず，EA，MA は逆に軟かくするわけである。 奏際この硬さ，軟らかさは，グラフトポリマー㵶維をさ わつた感じるそのと拈りである。

ここで注目すべきことは，上記のビニル化合物の作用 の相違はビニルポリマーの二次転移点に密接に対応して いることである。これらのポリマーの二次転移点は第 6 表のようである。つまり二次転移点の高いものは硕く し，低いいのは㜞らかくなる。

第6表 ビニルポリマーの二炊転移点とグラフト

\begin{tabular}{|c|c|c|c|}
\hline \multirow{2}{*}{$\begin{array}{l}ヒ=d \\
\text { 化 合 物 }\end{array}$} & \multicolumn{2}{|c|}{$\begin{array}{l}\text { ビ二ルポリマーの二次 } \\
\text { 車移点 } \\
\left.{ }^{\circ} \mathrm{C}\right)\end{array}$} & \multirow{2}{*}{$\begin{array}{l}\text { グラフトポりマ } \\
\text { 一の硬さの変化 }\end{array}$} \\
\hline & (a) & (b) & \\
\hline MMA & 120 & 125 & 大（硬） \\
\hline AN & 100 & $\sim 100$ & 小 $(" 1)$ \\
\hline VAC & 33 & 38 & 変化せす \\
\hline $\mathrm{MA}$ & 25 & 21 & 小（軟） \\
\hline EA & -5 & -5 & 大 (11) \\
\hline
\end{tabular}

注：(a )は Schmieder, Wolf ${ }^{2}$ によるものであり，

(b)はわれわれの值でする゙。

\section{VII. お りに}

以上グラフト重合体瀻維の性質について，いくらか述 ベた。しかしながら問題は㵶維としての性質でなく織物 としてどらかということである。

そこでわれわれは，ナイロンスチレン系のグラフト重
合体蟣維より紡績して絨物を作つた。この織物の性質に ついてはすでに発表されている゙。結諭としてこれは特 によいものとはいい難い。しかしょがらナイロンステー プルからグラフト重合を経て織物に至るまで無数のブロ セスがあり，優れた最終製品を得るためには，これらの プロセスについて多くの検討が必要であり，これは莫大 なる金と時間のかかる仕事である。現在ではこれらに関

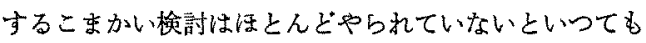
過言ではないであるう。グラフト重合により傮れた緎維 が得られるかとらかは未知の問題である。しかし少なく とも検討するだけの価値は，あるものと考えられる。

\section{VIII. 総括}

ナイロンに前照射法によりいらいらなビニルモノマー をグラフト垂合させた織維についてその性質を調べた。 強力 $(\mathrm{g})$ はグラフト重合によつてあまり変化しないが， 強度 $(\mathrm{g} / \mathrm{d})$ は低下する。二次転移点のナイロンより高い ビニルポリマーの枝づけにより㓮性率およびヤング率は 堌加する。二次耺移点の低いるのは近は風性率お上びヤ ング率は增加する。グラフト重合により弾性回復性，吸 水性，染色性，熱固定性などはいずれも低下寸る。

なお、ここに記したデータの一部は既発表のものと侎 一部重復しているが，統一をもたすために再録した。

文献

1)筥原康夫；高分化，17，197（1960）

2) K. Schmieder and K. Wolf ; Kolloid Zeit., 134, 149 (1953)

3) Y.Shinohara; J. Appl. Polymer Sci., 1, 251 (1959)

4) 向山鋭次; 放射線高分子，3，3 (1961)

(昭和 36 年 7 月 10 日受理)

ポリオレフィンを幹とするグラフト重合体繊維の性質

$$
\begin{aligned}
& \text { 東洋レーヨン株式会社 篠原康泶 } \\
& \text { 米研 }
\end{aligned}
$$

\section{PROPERTIES OF POLYOLEFINE GRAFT FILAMENTS}

By Yasuo Shinohara

(Ceniral Researeh Laboratory, Toyo Rayon Co. Ltd., Otru City, Shiga Prefecture, Japan)

2 methyl 5 vinyl pyridine(MVP), styrene, methyl methacylate (MMA), vinyl acetate (VAc) and methyl acrylate (MA)were grafted onto polyethylene and polypropylene filament by pre-irradiation method and various properties of these graft filaments were measured. 